\title{
Evaluation of Nanocrystalline Hydroxyapatite Plus Platelet-Rich Fibrin as A Grafting Material Around Dental Implant After Narrow Alveolar Ridge Splitting
}

\author{
AbdUllah I. Abd Rabbouh"1, Ibraheem M. Mwafey', Fathy A. Abo Zaid"1, Ahmed K. Mohammed ${ }^{1}$
}

Codex : 09/2021/10

Aadj@azhar.edu.eg

\section{KEYWORDS}

Platelet-rich fibrin, nanocrystalline hydroxyapatite, narrow alveolar ridges, splitting and expansion, piezosurgery, regenerative Materials

\begin{abstract}
Aim: This study was carried out to evaluate clinically and radiographically using of nanocrystalline hydroxyapatite ( $\mathrm{NcHA}$ ) and platelet-rich fibrin (PRF) as a grafting materials around the implant after narrow alveolar ridge splitting and expansion by piezoelectric surgery. Subjects and methods: twenty systemically healthy patients with partial edentulous narrow maxillary alveolar ridges were selected from those attending at the Out-Patient Clinic, Oral Medicine and Periodontology Department, Faculty of Dental Medicine, Al-Azhar University, Assiut Branch. Then they divided randomly into the following equal groups. First Group, ten patients with partial edentulous narrow maxillary anterior alveolar ridges, treated by piezoelectric ridge splitting and expansion with simultaneous implant placement into their ridges. Second Group, ten patients with partial edentulous narrow maxillary anterior alveolar ridges treated by piezoelectric ridge splitting and expansion with simultaneous implant placement into their ridges; combined with application of nanocrystallin hydroxyapatite bone graft mixed with platelet rich fibrin (PRF). Patients were evaluated clinically to assess probing depth and implant stability quotient, and radiographically to assess the alveolar ridge width, marginal bone loss, and bone density measurement parameters at baseline, 6, 9, and 12 months. Results: Among the studded groups, there is a high statistically significant difference between the clinical and radiographic measurements. Conclusion: Usage of combination of nanocrystallin hydroxyapatite bone graft and platelet rich fibrin as a grafting materials around the implant after narrow alveolar ridge splitting and expansion by piezoelectric surgery appeared significantly superior to immediate implant placement alone.
\end{abstract}

\section{INTRODUCTION}

Dental implants provide a gold standard method of successful and predictable treatment of partial or complete edentulism. To achieve long-term optimal functional and esthetic results with dental implants, one major prerequisite is sufficient bone quantity and quality at the recipient site. ${ }^{(1)}$ 
Ridge augmentation using autograft, block graft and guided bone regeneration (GBR) using membrane have proved to be successful in highly resorbed ridges to achieve result in horizontal and vertical dimension. But several drawbacks including invasiveness, additional donor site, resorption of grafting materials, membrane collapse and exposure to infection and delaying of implant installation for grafting maturation. More non-invasive technique of ridge splitting and expansion can be carried out easily, without much trauma to the patient. ${ }^{(2)}$

The piezosurgery device uses low-frequency piezoelectric ultrasonic vibrations precisely cutting the bone without cutting the soft tissue. Because the instrument's tip vibrates at different ultrasonic frequencies, since hard and soft tissues are cut at different frequencies, a "selective cut" enables the clinician to cut hard tissues while sparing fine anatomical structures (e.g., schneiderian membrane, nerve tissue). ${ }^{(3)}$

Preliminary experimental studies have shown that nano-sized ceramics may represent a promising class of bone graft substitutes due to their improved osseo-integrative properties. Accordingly, a synthetic nano-crystalline hydroxyapatite ( $\mathrm{NcHA}$ ) bone graft has been introduced for augmentation procedures. Advantages of $\mathrm{NcHA}$ material are osteoconductivity, biocompatibility, bioresorbablity, and close contact. A special feature of nanostructured materials is an extremely high number of molecules on the surface of material. ${ }^{(4)}$

Platelet-rich fibrin (PRF) consists of an autologous leukocyte-platelet-rich fibrin matrix composed of a tetra molecular structure, with cytokines, platelets, and stem cells within it, which acts as a biodegradable scaffold that favors the development of micro-vascularization, angiogenesis stimulating capacity and releases growth factors. It has been reported that (PRF) gradually released autologous growth factors are more effective for the proliferation and differentiation of osteoblasts. Regarding the effect of PRF on bone healing, studies have reported the effect of PRF on implant stability and healing. ${ }^{(5)}$

\section{AIM OF THE STUDY}

The present study was carried out to evaluate clinically and radiographically using of nanocrystalline hydroxyapatite ( $\mathrm{NcHA}$ ) plus platelet-rich fibrin (PRF) as a grafting materials around the implant after narrow alveolar ridge splitting and expansion by piezoelectric surgery.

\section{PATIENTS AND METHODS}

\section{Study setting and population:}

Twenty systemically healthy patients (11 males and 9 females, ranged in age from 21-47 years with mean age of 34 years) with partial edentulous narrow maxillary anterior alveolar ridge were motivated to implant placement. Patients were selected from those attending at the Out-Patient Clinic, Oral Medicine and Periodontology Department, Faculty of Dental Medicine, Al-Azhar University, Assiut Branch. Then they were divided randomly into 2 equal groups. Group I, ten patients with partial edentulous narrow alveolar ridges, treated by piezoelectric ridge splitting and expansion with simultaneous implant placement into their ridges. Group II, ten patients with partial edentulous narrow alveolar ridges treated by piezoelectric ridge splitting and expansion with simultaneous implant placement into their ridges; combined with application of nanocrystalline hydroxyapatite bone graft Nano Bone ${ }^{\circledR}$ (NanoBone, ARTOSS GmbH Company, Rostock, Germany) mixed with platelet rich fibrin (PRF).

\section{Inclusion criteria:}

- Missing a single or multiple teeth in the anterior maxillary region after at least three months of socket healing.

- Crestal residual ridge width ranging from 3 to 5 $\mathrm{mm}$ at the crest and 6 to $8 \mathrm{~mm}$ at the basal part of the ridge.

- Residual ridge with sufficient vertical bone height with a minimum of $10 \mathrm{~mm}$ height. 


\section{Exclusion criteria:}

- Conditions that complicate wound healing, for example, uncontrolled diabetes (defined as HBA1c level $>7 \%$ ) or smoking

- Perforated and/or lost labial bony plate.

- Obvious undercut on the labial cortical plate.

- Severe parafunctional habits; bruxism and clenching.

\section{Surgical procedures:}

- A full thickness flap reflection of the labial and palatal mucoperiosteal flap was done.

- Using piezoelectric surgery unit (piezotome ${ }^{\circledR}$ solo, acteon, satelec, France) a horizontal crestal cut was produced along the crest of the bone. The cut depth extended through the cortical bone to reach the spongy bone. The depth of the horizontal cut was approximately $2-3 \mathrm{~mm}$ shorter than the overall length of the implant to be placed. Two vertical cuts if needed were made and these were connected to the horizontal crestal cut, then drilling at the target site of implant placement from pilot drill to the final drill according to the manufacture instructions in a length approximately $2-3 \mathrm{~mm}$ longer than the horizontal cut.

- The previously selected MULTY SYSTEM ${ }^{\circledR}$ (Multy System s.r-Implantoprotesi \& biomateriali-monza-Italy) dental implants were placed in the sites and positioned at the level of the alveolar ridge crest.

\section{Preparation of platelet rich fibrin}

The PRF was prepared by collection of venous blood $(10 \mathrm{~mL})$, in two sterile glass coated plastic vacutainer tube without anticoagulant and centrifuged at 3000 revolutions per minute (rpm) for $10 \mathrm{~min}$ at room temperature. After centrifugation, 3 layers were obtained: a cellular plasma (platelet poor plasma) was concentrated at the top and was collected by syringe; fibrin clots and red blood corpuscles were removed from the tube with a tweezers; a PRF clot was immediately separated from red blood corpuscles with a scalpel. ${ }^{(6)}$

- In group II, the remaining distraction-gap filled with a combination of Nano Bone ${ }^{\circledR}$ (NanoBone, ARTOSS GmbH Company, Rostock, Germany) and platelet-rich fibrin (PRF)

- After 6 months, submerged healing period, the patients were called back for the second stage surgery. Definitive abutments were tightened using $35 \mathrm{Ncm}$ torques. The final porcelain prostheses were cemented.

\section{Clinical photographs:}

In two groups, every procedure was documented by photographs at different observation periods of the study (fig 1).

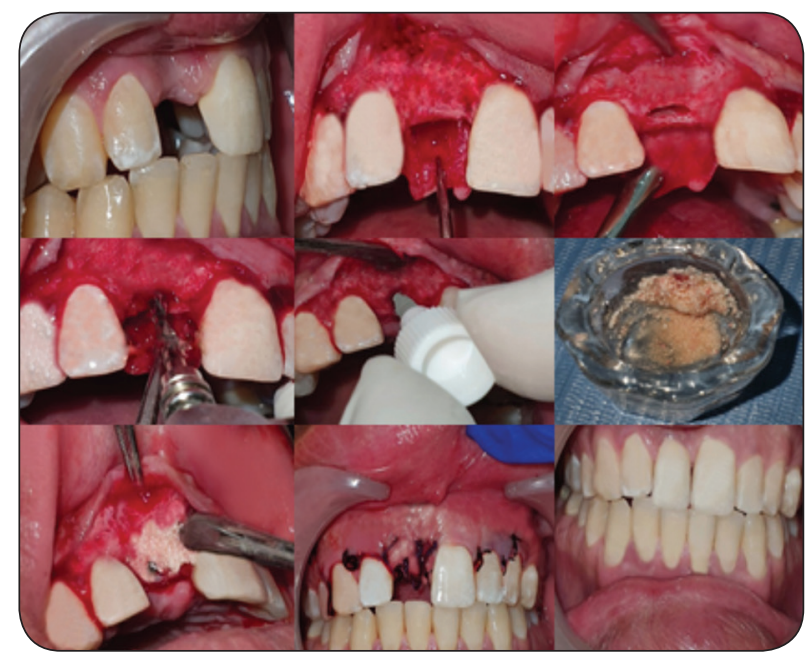

\section{Implant Evaluation:}

Probing depth (PD): It was measured as the distance from the crest of gingival margin to the bottom of the gingival sulcus at four sites around implants.

Implant Stability: All implants were evaluated for primary stability once after implant insertion with an Osstell ${ }^{\mathrm{TM}}$ (Osstell ${ }^{T M}$, Integration Diagnostics Ltd., Goteborgsvagen, Sweden). Additional resonance frequency analysis (RFA) measurements were taken at the 6 months follow-up re-entry for prosthetic procedures. 
Post-operative ridge width: It was measured with Cone beam computed tomography (CBCT) at the day of the implant placement (baseline), 6 and 12 month.

Measurement of marginal bone loss (MBL): Implant MBL around the implant was evaluated at the day of the implant placement (baseline) and on the followup visits at 6 and 12 months. Measurements were made mesially and distally for each implant.

\section{Statistical analysis:}

The data were collected; tabulated and statistical analysis was performed with International Business Machines (IBM)Ò( IBM, 914 Armonk, New York, U.S.A) Statistical Package for Social Sciences (SPSS) statistics version 20 for Windows.

\section{RESULTS}

The period of observation of the implants was 12 months. No abnormal reactions or complications were observed during the observation periods of the study. The results of the examined groups of this study were recorded, tabulated and statistically analyzed.
Changes in probing depth: probing depth increased gradually by the end of the study in all groups. The accretion of probing depth in all groups occurred but it still in acceptable range $(\leq 3 \mathrm{~mm})$.

Changes in Implant Stability Quotient (ISQ): ISQ increased at 6 month of observation interval in all groups. When comparing ISQ between groups, showed no statistical significant difference at baseline and statistical significant difference at 6 month interval of observation period.

\section{Changes in alveolar ridge width:}

Comparing pre-operative \& post-operative alveolar ridge width between groups; it showed no statistical significant difference between all groups pre-operatively with statistical significant difference at 6 and 12 months interval of observation period.

Changes in Marginal bone level (MBL): When comparing G II VS. G I, it showed no statistical significant difference at baseline observation period, while it showed statistical significant difference during 6 and 12 month of observation periods of the study. This diminution in marginal bone level in all groups occurred but it still in acceptable range ( $\leq$ $1.5 \mathrm{~mm}$ in first year after implant placement).

Table (1): Showing minimum, maximum, means and standard deviations of peri implant probing depth $(P P D)$ and implant stability values, within each group and between groups at different intervals, along with significance level.

\begin{tabular}{|c|c|c|c|c|c|c|c|c|c|c|c|c|c|c|c|}
\hline \multirow{3}{*}{ Variables } & \multicolumn{15}{|c|}{ PPD } \\
\hline & \multicolumn{5}{|c|}{ After $6 \mathrm{~m}$} & \multicolumn{4}{|c|}{ After 9m } & \multicolumn{5}{|c|}{ After $12 m$} & \multirow{2}{*}{ p-value } \\
\hline & Mean & \multicolumn{2}{|c|}{ SD } & Min & Max & Mean & SD & Min & Max & \multicolumn{2}{|c|}{ Mean } & SD & Min & $\operatorname{Max}$ & \\
\hline Group I & $2.38^{\mathrm{aC}}$ & \multicolumn{2}{|c|}{0.18} & 2.25 & 2.75 & $2.60^{\mathrm{aB}}$ & 0.21 & 2.25 & 3.00 & \multicolumn{2}{|c|}{$2.88^{\mathrm{aA}}$} & 0.24 & 2.50 & 3.25 & $<0.001 *$ \\
\hline Group II & $1.90^{\mathrm{bC}}$ & \multicolumn{2}{|c|}{0.27} & 1.50 & 2.25 & $2.18^{\mathrm{bB}}$ & 0.29 & 1.75 & 2.50 & \multicolumn{2}{|c|}{$2.35^{\mathrm{cA}}$} & 0.34 & 1.75 & 2.75 & $<0.001 *$ \\
\hline p-value & \multicolumn{5}{|c|}{$<0.001 *$} & \multicolumn{4}{|c|}{$0.003 *$} & \multicolumn{5}{|c|}{$0.001 *$} & \\
\hline \multirow{3}{*}{ Variables } & \multicolumn{15}{|c|}{ Implant stability } \\
\hline & \multicolumn{6}{|c|}{ Primary stability } & & \multicolumn{6}{|c|}{ Secondary stability } & & \multirow{2}{*}{ p-value } \\
\hline & \multicolumn{2}{|c|}{ Mean } & SD & \multicolumn{2}{|c|}{ Min } & Max & & Mean & & D & Mi & & Max & & \\
\hline Group I & 63.30 & & 3.65 & & & 69.00 & & $69.00^{\mathrm{cA}}$ & & 70 & 66. & & 72.00 & & $<0.001 *$ \\
\hline Group II & 66.00 & & 3.06 & & & 69.00 & & $76.60^{\mathrm{aA}}$ & & 91 & 70. & & 80.00 & & $<0.001 *$ \\
\hline p-value & & & & 0.115 & & & & & & $<0$. & $01 *$ & & & & \\
\hline
\end{tabular}


Table (2): Showing minimum, maximum, means and standard deviations of alveolar ridge width and marginal bone loss (MBL), within each group and between groups at different intervals, along with significance level.

\begin{tabular}{|c|c|c|c|c|c|c|c|c|c|c|c|c|c|}
\hline \multirow{3}{*}{ Variables } & \multicolumn{13}{|c|}{ Pre and Post-operative alveolar ridge width } \\
\hline & \multicolumn{4}{|c|}{ Baseline } & \multicolumn{4}{|c|}{ After $6 \mathrm{~m}$} & \multicolumn{4}{|c|}{ After 12m } & \multirow{2}{*}{ p-value } \\
\hline & Mean & SD & Min & Max & Mean & SD & Min & Max & Mean & SD & Min & Max & \\
\hline Group I & $4.02^{\mathrm{aC}}$ & 0.43 & 3.30 & 4.60 & $6.31^{\mathrm{bA}}$ & 0.66 & 5.40 & 7.30 & $5.80^{\mathrm{bB}}$ & 0.67 & 5.00 & 6.80 & $<0.001 *$ \\
\hline Group II & $3.91 \mathrm{ac}$ & 0.54 & 3.00 & 4.80 & $7.05^{\mathrm{aA}}$ & 0.47 & 6.20 & 7.80 & $6.90^{\mathrm{aB}}$ & 0.49 & 6.00 & 7.60 & $<0.001 *$ \\
\hline \multirow[t]{2}{*}{ p-value } & \multicolumn{4}{|c|}{$0.880 \mathrm{~ns}$} & \multicolumn{4}{|c|}{$0.014 *$} & \multicolumn{4}{|c|}{$0.002 *$} & \\
\hline & \multicolumn{13}{|c|}{ MBL } \\
\hline Group I & $0.00^{\mathrm{aC}}$ & 0.00 & 0.00 & 0.00 & $0.69^{\mathrm{aB}}$ & 0.14 & 0.40 & 0.90 & $1.19^{\mathrm{aA}}$ & 0.14 & 1.00 & 1.40 & $<0.001^{*}$ \\
\hline Group II & $0.00^{\mathrm{aC}}$ & 0.00 & 0.00 & 0.00 & $0.42^{\mathrm{cB}}$ & 0.16 & 0.20 & 0.60 & $0.77^{\mathrm{cA}}$ & 0.18 & 0.50 & 1.10 & $<0.001 *$ \\
\hline p-value & \multicolumn{4}{|c|}{ 1ns } & \multicolumn{4}{|c|}{$<0.001 *$} & \multicolumn{4}{|c|}{$<0.001 *$} & \\
\hline
\end{tabular}

\section{DISCUSSION}

The purpose of the present study was to evaluate the efficacy of nano-crystalline hydroxyapatite (NcHA) and platelet-rich fibrin (PRF) as regenerative materials around the implant after splitting and expansion of narrow alveolar ridges by piezoelectric surgery.

In this study 3 dimensional (CBCT) was used to determine accurately the quantity and quality of bone at the specific sites for implant placement, the internal morphology of the bone, evaluate drill location with respect to critical anatomical landmarks, and the follow-up evaluation for pre and post-operative ridge width and also provide radiological densitometric readings of bone in (Hounsfield Units). Shahidi et al (2018). ${ }^{(7)}$

No implant mobility was observed clinically and this was further confirmed by the radiographic results as a sign of proper osseointegration; these findings were in agreement with studies of Papaspyridakos et al (2012) and Szmukler et al (2000) ${ }^{(8,9)}$

In this trial, the means of primary implant stability quotient (ISQ) values were 63.30 and 66 for group I and II respectively. The present study showed no statistically significant difference between the groups; these findings were parallel to the results reported by Kesharwani et al (2019) ${ }^{(10)}$

The secondary implant stability quotients at 6 months showed a mean values 69.00 and 76.60 for group I and group II respectively; these findings is in accordance with results recorded by Östman et al (2006). ${ }^{(11)}$

In this study after 6 months the average gain in the alveolar ridge widths were 2.29 and $3.14 \mathrm{~mm}$ in group I and II respectively. These results were similar to Blus et al (2010) ${ }^{(12)}$, Chiapasco et al (2006) ${ }^{(13)}$ and Anitua et al (2013) ${ }^{(14)}$, they reported, a final mean bone gain of $3 \mathrm{~mm}$ in piezosurgical ridge splitting.

There was a gradual increase in marginal bone loss during the observational periods of the present study in all groups. With a mean values $0.69 \mathrm{~mm}$ and $0.42 \mathrm{~mm}$ for group I and II respectively at 6months, increased to $1.19 \mathrm{~mm}$ and $0.77 \mathrm{~mm}$ for group I and II respectively at the end of observation periods at 12 months. This in accordance with success criteria defined by Albrektsson and Zarb (1993), ${ }^{(15)}$ and Strietzel et al (2002). ${ }^{(16)}$ 


\section{CONCLUSION}

Usage a mixture of platelet rich fibrin and nanocrystalline hydroxyapatite appeared significantly superior to immediate implant placement alone.

\section{REFERENCES}

1. Braut V, Bornstein M, Belser U, Buser D. Thickness of the anterior maxillary facial bone wall-a retrospective radiographic study using cone beam computed tomography. International Journal of Periodontics and Restorative Dentistry. 2011; 31:125-31.

2. Khairnar S, Khairnar D, Bakshi K. Modified ridge splitting and bone expansion osteotomy for placement of dental implant in esthetic zone. Contemporary clinical dentistry. 2014; 5:110-14.

3. Blus C, Szmukler-Moncler S. Split-crest and immediate implant placement with ultra-sonic bone surgery: a 3-year life-table analysis with 230 treated sites. Clinical Oral Implants Research. 2006; 17:700-7.

4. Elgendy A, Shady A. Clinical and radiographic evaluation of nanocrystalline hydroxyapatite with or without platelet-rich fibrin membrane in the treatment of periodontal intrabony defects. Journal of Indian Society of Periodontology. 2015; 19:61-65.

5. Kökdere N, Baykul T, Findik Y. The use of platelet-rich fibrin (PRF) and PRF-mixed particulated autogenous bone graft in the treatment of bone defects: An experimental and histomorphometrical study. Dental research journal. 2015; 12:418-22.

6. Dohan M, Choukroun J, Diss A, Dohan SL, Dohan AJ, Mouhyi J, et al. Platelet-rich fibrin (PRF): a secondgeneration platelet concentrate. Part I: technological concepts and evolution. Oral Surgery, Oral Medicine, Oral Pathology, Oral Radiology, and Endodontology. 2006; 101:37-44.

7. Shahidi S, Zamiri B, Abolvardi M, Akhlaghian M, Paknahad M. Comparison of dental panoramic radiography and $\mathrm{CBCT}$ for measuring vertical bone height in different horizontal locations of posterior mandibular alveolar process. Journal of Dentistry. 2018; 19:83-91.

8. Papaspyridakos P, Chen J, Singh M, Weber P, Gallucci G. Success criteria in implant dentistry: a systematic review. Journal of dental research. 2012; 91:242-8.

9. Szmukler S, Piattelli A, Favero A, Dubruille H. Considerations preliminary to the application of early and immediate loading protocols in dental implantology. Clinical oral implants research. 2000; 11:12-25.

10. Kesharwani P, Paul D, Tiwari R, Pentakota N, Kuntamukkula V, Kardwal K. Implant Placement with Ridge Splitting and PRF Placement A Case Report. J Craniofac Surg 2019;24:88-94.

11. Östman O, Hellman M, Wendelhag I, Sennerby L. Resonance frequency analysis measurements of implants at placement surgery. International Journal of Prosthodontics. 2006;19:77-83.

12. Blus C, Szmukler S, Vozza I, Rispoli L. Split-crest and immediate implant placement with ultrasonic bone surgery (piezosurgery): 3-year follow-up of 180 treated implant sites. Quintessence international. 2010; 41:463-9.

13. Chiapasco M, Ferrini F, Casentini P, Accardi S, Zaniboni M. Dental implants placed in expanded narrow edentulous ridges with the Extension Crest device. A 1-3-year multicenter follow-up study. Clin Oral Implants Res. 2006; $17: 265-72$

14. Anitua E, Begoña L, Orive G. Clinical evaluation of splitcrest technique with ultrasonic bone surgery for narrow ridge expansion: status of soft and hard tissues and implant success. Clinical implant dentistry and related research. 2013; 15:176-87.

15. Albrektsson T, Zarb A. Current interpretations of the osseointegrated response: clinical significance. International Journal of Prosthodontics. 1993;6:95-105.

16. Strietzel P, Nowak M, Küchler I, Friedmann A. Periimplant alveolar bone loss with respect to bone quality after use of the osteotome technique: results of a retrospective study. Clin Oral Implants Res. 2002; 13:508-13. 


\title{
تقييم رقعة من حبيبات الهيدروكسى ابيتايت متناهية الصغر

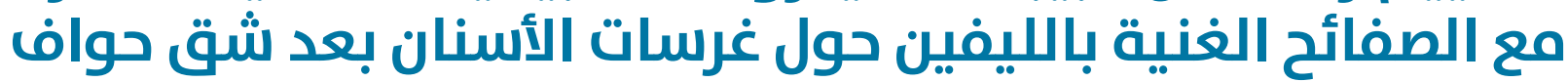 الفك السنخية الضيقة
}

\author{
عبد الله ابراهيم عبدربه *، ابراهيم محمود موافى، فتحى عبد العظيم أبوزيلد، أحمد قاسهم محمد \\ 1. قسـم طب الفم وأمراض اللثة، والتشـيص والأشعة، كلية طب الأسنان، جامعة الازهر، أسيوط، مصر \\ * ABDULLAHBESHRAH923.EL@AZHAR.EDU.EG *
}

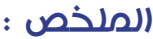

الهدف: أجريت هذه الدراسـة لتقييم فعالية حبيبات الهيدروكسى ابيتايت متناهية الصغر والصفائح الغنية بالليفين كمواد مجدددة للأنسجة متزامنا مع وضع غرسـات الأسنان بعد شـق وتوسعة حواف الفك السـنخية الضيقة بواسطة تقنية الموجات فوق الصوتية.

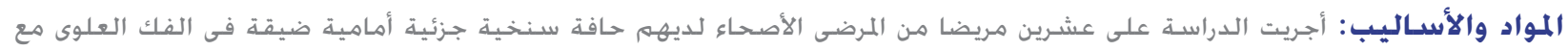

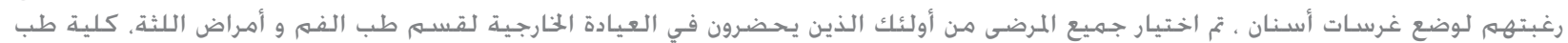

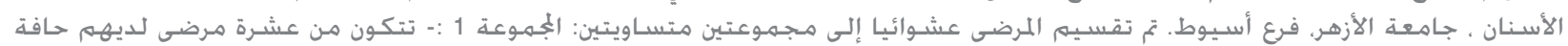

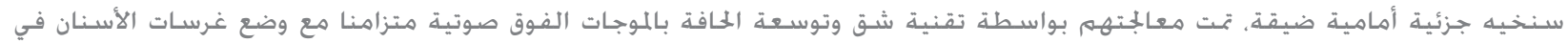

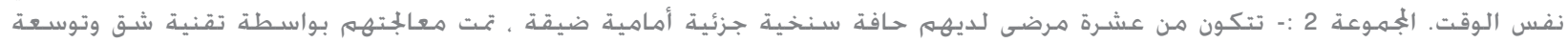

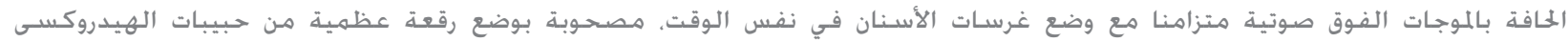

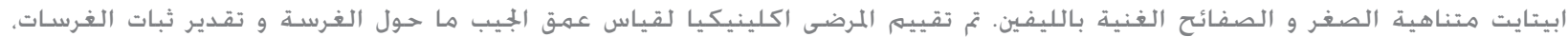

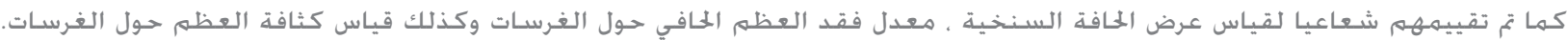
النتائه: أظهرت نتائج الدراسـة أن هناك فروق ذات دلالة إحصائية فيما يتعلق بالتقييم الاكلينيكى والإشعاعي في مجهموعة الدراسـة. الخلاصة: بدا استخدام حبيبات الهيدروكسى ابيتايت متناهية الصغر مع مزيتج من الصفائح الغنية بالليفين متفوقا بشكل كبير على الغرس الفورى وحده.

الكعلمات المفتاحية: الصفائح الغنية بالليفين ، حبيبات الهيدروكسى ابيتايت متناهية الصغر ، حافة سنخية ضيقة ، شق وتوسعة

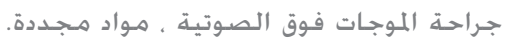


186 
